\title{
'OUT OF WHOSE HIVE THE QUAKERS SWARM'D': POLEMICS AND THE JUSTIFICATION OF INFANT BAPTISM IN THE EARLY RESTORATION
}

\author{
JONATHAN WARREN \\ University of Texas
}

\begin{abstract}
The English Civil War brought an end to government censorship of nonconformist texts. The resulting exegetical and hermeneutical battles waged over baptism among paedobaptists and Baptists continued well into the Restoration period. A survey of the post-Restoration polemical literature reveals the following themes: 1) the polemical 'slippery slope' is a major feature of these tracts. Dissenting paedobaptists believed that Baptists would inevitably become Quakers, despising baptism altogether, and that the resulting social instability would allow the tyranny of Roman Catholicism to reemerge in England. Baptists for their part compared the tyranny of paedobaptist argumentation to the tyranny exercised by Roman Catholics. AntiQuakeriana and Anti-Popery were both central 'devil terms' in this polemical warfare; 2) the exegesis of biblical texts underlying infant baptism revealed contrary understandings of how the bible fit together as a whole. Baptists tended to read Old and New Testaments disjunctively, whereas paedobaptists saw continuity absent explicit abrogation; 3) scholastic theology continued to undergird the arguments of all parties. Especially relevant to this discussion was debate over the proper 'matter' and 'form' of baptism. Here exegetical and hermeneutical disputes were also relevant. This study reveals that patterns of reading Scripture in each community were informed by traditions and practices, and that the search for the objective 'literal' sense of the text was bound to be unavailing.
\end{abstract}

KEY WORDS: Restoration, Baptism, Paedobaptists, Baptists, Exegesis

Among England's Puritans, paedobaptism was a practice in search of an adequate justification. Moderate Puritan nonconformists routinely excoriated Baptists and Quakers, but their opposition to the salvific efficacy of the sacraments seemed to undermine their own practice of infant baptism. As Thomas Bedford, a leading Puritan advocate of baptismal regeneration, put it, 'Why do the Ministers cry down the Anabaptists for denying Infant-Baptism, when they can show us no good that cometh by it?' (Bedford 1638: 92). Debates between Baptists and paedobaptists convulsed the country from the lifting of censorship in the early 1640s until the Restoration. Paul Lim notes

* JONATHAN WARREN (PhD 2014, Vanderbilt University) is a campus minister within the InterVarsity Texas Christian Scholars Network at the University of Texas at Austin. Email: jwarren4@gmail.com. 
that 'Anabaptist' tracts 'so galvanized the community of the godly into action that the London bookseller George Thomason collected over 125 tracts written between 1642-1660 on this issue' alone (Lim 2004: 55). Among Dissenters, however, the debates did not cease with the Restoration. The writings of the Particular Baptists, especially those of Henry Danvers, and General Baptists, especially Thomas Grantham, provided renewed vigor to the debate.

The polemical, exegetical, and doctrinal context of these post-Restoration debates over baptism among Dissenters will be evaluated thematically below. The following themes emerge in the literature: first, each side, paedobaptist and anti-paedobaptist, polemically imaged the other as giving rise to monstrous distortions of true Christianity. In the case of paedobaptists, the Baptists represented a slippery slope to Arminianism, Quakerism and finally to Ranterism and Familism and so to civil disorder and chaos. By no means was this a new argument: as Paul Lim has indicated, it was commonly made in the 1640 s as well. The Presbyterians had early on established the theme: 'leave Calvinism-Presbyterianism, then all hell will break loose!' (Lim 2012: 90). The paedobaptists of Presbyterian and Independent leanings followed suit in making this charge in the 1670s and 1680s. Likewise, the Baptists excoriated paedobaptists for failing to be fully Protestant and allowing Popery in through the back door. As Henry Danvers put it, '[they] separate from Rome as the false Church, and yet own their Baptisme, the Foundation Stone thereof' (Danvers 1673: 258).

Secondly, there were three key exegetical foci of the debate: the meaning of the Abrahamic covenant in Genesis 17, the meaning of hagia in 1 Corinthians 7:14, and the meaning of 'make disciples' in Matthew 28. Disagreements about these three exegetical touch points informed much of the debate between paedobaptists and Baptists. There was in addition a corresponding hermeneutical dispute about how to read the antitype to circumcision in the Old Testament and its connection to the Covenant of Grace. For most paedobaptists, this was the dispositive issue. As Giles Firmin put it, if God hath now since Christ is come, nulled and repealed this Covenant with Abraham and his Seed, I say, if this can be infallibly proved, the controversie between us and the Anabaptists is at an end; for then, no Covenant, no Seal' (Firmin 1688: 7). In particular, although all the paedobaptists and Baptists believed in a regulative use of Scripture, such that one had to have a warrant for everything done in worship (except 'circumstantials'), the disjunction Baptists saw between circumcision and baptism meant that they were looking for an 'express precept' to baptize infants whereas paedobaptists insisted that the precept could be deduced 'by good and necessary consequence' through the typological reading of Scripture.

Thirdly, there was a corresponding philosophical issue. These divines, disconnected though many of them were from the intellectual life of London, 
Oxford, and Cambridge, were still steeped in the vocabulary of Protestant scholasticism, and thus the debate about baptism concerned the proper 'matter' and 'form' of baptism. Those favoring baptismal regeneration in the Church of England had different answers to these questions, but Dissenting paedobaptists agreed with Baptists that the matter of the church was 'visible saints', which made the ensuing discussions about how to distinguish the matter of baptism in paedobaptist terms from the Baptist matter an interesting one. The question of the 'form' or the mode in which baptism had to be conducted was a different matter, with different biblical metaphors undergirding the paedobaptist and the Baptist answers to the question.

\section{Of Quakerism, Popery, and the Slippery Slope}

In 1676, George Fox dashed off a broadside in which he thundered against externals in worship:

So see and examine, if this hath not been your own Condition, like the Jews: For your several sorts of Crossing and Sprinklings, and Washings with outward Water, that is used in Christendom by the Priests, which they call Baptism, doth not bring their People into one Body, nor to drink into one Spirit, as Christ's Baptism with his Spirit doth (Fox 1676: 7).

All Protestantism had an iconoclastic edge to it, concerned as it was in its inception that certain traditions, doctrines, and practices were unfaithful to the apostolic witness in Scripture. The key lay in determining just how much iconoclasm was consistent with civic order and a certain degree of hierarchy in the offices of the church.

Almost everyone agreed that Quakers were the chief fomenters of public disorder with their putative rejection of the authority of Scripture and their curiously Ranter-ish doctrine of the 'inner light'-'[a] Light that is kindled (I fear) by Hell fire', as one anti-Quaker pamphlet urged (Anonymous 1674: 14). Their rejection of all external forms in worship, and in particular the 'Quaking Pope, George Fox, with whom it is as impossible to Write calmly and Christianly as it is to write Sense' was iconic of public disorder (Anonymous 1674: 40). And so the most effective way for moderate Dissenters to show the danger of the 'Baptized Way' was to show that it led directly to Quakerism and to the breakdown of society. The charge usually revolved around the imputation of moral failure on the part of those drawn to 'Anabaptistry'-their hearts were schismatic, so they were instable and incapable of submission to just authority and so would inevitably destroy order altogether. Antinomianism and spiritual despair usually followed the foray into Anabaptism according to paedobaptists. Giles Firmin, a Restoration Presbyterian, would not even 'write what Corruptions in Doctrine I have heard among them besides these: out of whose Hive the Quakers swarm'd for the 
greater part, is well known: going from Gospel Light to Natural Light, and further they cannot go' (Firmin 1688: 82).

Interchangeable with the Quakers in the polemical literature were the Muenster and Leyden rebels. In the imagination of most Protestants, these were Anabaptists whose enthusiasm had reached new heights in their apocalyptic language, conquest of cities, and institution of polygamy, abolition of private property, and other evils. A whole range of apocryphal stories about the Anabaptists emerged from the pens of the Presbyterian and Independent pugilists. Henry Danvers, the Particular Baptist, chastised the exaggeration of these stories: 'For if Mr. Edwards in his Gangraene be to be believed (which it may be other Nations do that have got it) what Monsters of Men hath he represented the Independents and Anabaptists to be: Or Mr. Baxter himself to be credited in that horrid Calumney of the Anabaptists, Baptizing naked in these Countries... What unnatural Brutes would they be esteemed?' (Danvers 1673: 325).

It was easy enough for moderate Dissenters to make the association of anti-paedobaptism with the other range of bizarre behaviors practiced by the Muenster and Leyden rebels, but Baptists like Henry Danvers did not do themselves any favors by attempting to rehabilitate the Anabaptists's reputation. In Treatise of Baptism in 1673, Danvers argued that even if 'some Anabaptists in Germany did turn Ranters... can that justly be reflected upon the Principle, and upon the Innocent in other parts of the world, that hate and abhor all such ways and courses?' (Danvers 1673: 327). The paedobaptists seized upon the fact that Danvers tried to resuscitate the memory of the Muenster radicals as a sign that he wanted the same to occur in England. Obediah Wills was only to happy to show his readers how disturbing the German Anabaptists were:

as for [Danvers's] other witnesses, Munzer and John of Leyden, with the rest of that Faction, though he doth pertinaciously persist against the clearest evidences, in palliating or rather denying the horrid crimes laid to their charge, and withal (very disingenuously) reflects dishonour upon those of the Reformation, I shall not be at so much expence of time and Paper as to expose his gross aberrations herein, but quietly permit him to injoy the comfort and honour of such witnesses (Wills 1675: 154).

The ultimate telos of public disorder, the Puritans as good classicists knew, was tyranny. The most proximate tyranny they could think of was Popery, and so they urged the Baptists to cease their fissiparous tendencies lest the whole nation be placed back under the yoke of Catholicism. A anonymous pamphleteer urged, 
Shall it ever be the Character of the Non-Conformists, the more Liberty they have, the more they will Divide \& break one another? If this be Non-Conformity, Lord deliver every good Christian from it. Do you long to be hurried together into Prisons again? Will no place Unite you, but a nasty Dungeon? Nothing Sodder you but Persecution? Oh beware, beware; the next time he may Chastise you with Faggots, with Scorpions, with Devils; and do not think if once you are under Hatches again, that a few... sighs, Prayers, or Promises shall redeem you; you may e're long (you know not how soon) be doing Pennance together in Popish Limbo's (Anonymous 1674: 48).

The paedobaptists were at times willing to take some measure of responsibility for the rise of Anabaptistry themselves, at least rhetorically. Giles Firmin argued that because 'even good Men did not improve their Father-AbrahamsCovenant, nor their Infant-Baptism Covenant, as they ought', the effectiveness of infant baptism had lost its plausibility (Firmin 1684: 4, 6-7, 9). A pamphlet written in 1678 lamented the rise of the sect "who are now known by the name of Socinians, who decry, disclaim (yea disdain) all Water-Baptism' and argued that 'it hath no little conduced to mens calling in question on the Lawfulness of Infant Baptism, because they themselves have no more found (and others near ' $\mathrm{em}$ have no more evidence) the usefulness and profitableness thereof' (Anonymous 1678: 9, 31-2, 43). The pamphlet gave a detailed list of ways that parents could help a baptized child 'make use and improvement of its InfantBaptism' (Anonymous 1678: 23). In this more self-reflective, penitential key, the paedobaptists could acknowledge that it was in many cases a search for purity that motivated the Baptists in re-baptizing and in gathering churches.

Moreover, some paedobaptist pugilists like Richard Baxter were willing to distinguish, at least for the sake of argument, between 'two sorts of men called Anabaptists among us: The one sort are sober Godly Christians, who when they are rebaptized to satisfie their Consciences, live among us in Christian love and peace [...]. The other sort hold it unlawful to hold Communion with such as are not of their mind and way, and are schismatically troublesome and unquiet, in laboring to increase their Party' (Baxter 1675: sig. A4r). Likewise Obediah Wills declared that the Baptists's 'very constitution inclines them to nothing more than to rent, and tear, and divide the Church: The Zeal for their Opinion hath and doth still prove the greatest hindrance to the conjunction of Christians here in this Nation', but he did not begrudge Baptists their convictions about how and when to administer the rite per se so long as they did not separate from lawful churches (Wills 1674: 295). Hence Wills praised the Particular Baptist John Bunyan for his willingness to commune with paedobaptists in his church, at least for the sake of putting Danvers in his place (Wills 1674: 351). Aside from these caveats, however, paedobaptists by and large were certain that it was a peculiar distemper that led Baptists to separate from the godly, and that this schismatic tendency would lead them 
to Quakerism, Ranterism, and beyond, resulting in a new Popish tyranny over the nation.

By no means, however, were the paedobaptists alone in employing slippery slope arguments against their opponents. Already in 1663, the General Baptist Thomas Grantham had written against an unnamed 'Papist' that the Church of Rome could not be the true church because it lacked true baptism, it was a national church, and it lacked the 'true Ecclesiastical Marks of truly Antient Primitive or Apostolical Gathering, Constitution and Government'. Only churches which possessed the latter, namely the Baptist churches, were true churches (Grantham 1663: 41-2, 58). By 1671 he was applying these arguments to all paedobaptists, particularly Presbyterians and Congregationalists. Although they thought they were deriving the doctrine from Scripture, they were actually taking on a practice of Antichrist, since it was 'innovated, after the holy Scriptures were written' and 'came in stealing (as it were) being for a considerable time left at liberty (a sign it was not from Heaven)' (Grantham 1671: 61).

The reason it became normative in the Popish churches was that it was believed necessary to the salvation of infants, but 'the grounds upon which paedobaptism was at first urged, are now in a manner wholly declined, and new grounds daily invented whereon to build it, which are no sooner laid, but raized again by some of its own favorites' (Grantham 1671: 63). By holding on to the practice, and by holding on to the form of 'sprinkling' rather than trine immersion, the paedobaptists opened the door to Popery. Against the Anglican apologist Edward Stillingfleet, Grantham argued that any clarification sought outside of Scripture in the tradition to confirm the practice of infant baptism was 'altogether unlike a Protestant: what are the Sacraments darkly laid down in the Scripture that we know not when and to whom they belong without Tradition'? (Grantham 1674: 34). To allow a probative value to tradition here would be to admit 'other innovations of Popery, or other sects' (Grantham 1674: 23).

At times Grantham could suggest an analogy between the tyranny engaged in by both Presbyterians and Catholics. In one of the quaeries sent to him by Presbyterians, the interlocutor asked why Grantham 'unchurches' almost all churches on earth, to which Grantham replied that this was exactly the same question put to Luther by the Catholics, and that the Presbyterians should be ashamed to 'take up the Papists weapons' (Grantham 1676: 36). The paedobaptists, by telling Christians 'that if we have Communion with wicked men and Ministers in the Lords supper, and in their Parish-worship, we are not defiled thereby', were weakening the defenses of the godly against sinister Jesuits who said the same thing (Danvers 1675a: 195). Against the Presbyterian claims that the schism of the Baptists was aiding the Papists, Grantham could likewise retort, "If now we may hold Communion with the 
Paedobaptist, then come the Quakers and plead, That though they do indeed deny our Faith towards God, or the Lord Jesus Christ, as our own carnal imagination; yet they grant that Faith mentioned... to be true Faith... and urge that our separation from them is unwarrantable' (Grantham 1680: 4).

Henry Danvers, writing against Richard Baxter, was willing to call him a crypto-Papist even though he was 'sometimes a violent impugner of Popery', because he "hath also writ much for it... And that not only for the doctrine of Popery, but for much of their Discipline also' (Danvers 1675a: 218-19). Not only that, but Baxter, that ostensible critic of papal tyranny, was 'notoriously guilty' of dogmatic and 'severe censuring and judging of others that embrace not [his] sayings as Oracles, and magisterially too' (Danvers 1675a: 260-1; Danvers 1676: 13). Both paedobaptists and Baptists, then, were willing to invoke the specter of Popery against each other. By weakening Dissenting churches, either by schism or by impurity, respectively, each side was creating the conditions within which Catholics could return to power within England and establish a new sort of tyranny.

\section{Exegetical and Hermeneutical Disputes}

Rowan Williams has noted in his discussion of Origen's theology that he was the first Christian theologian to 'comment in extenso and by continuous exposition, upon the Scriptures', such that canonical, theological exegesis took on a 'problem-solving' function for him against his opponents. A 'prayerful Catholic reading' of the whole biblical text could defeat opponents such as Celsus and Heracleon because they had failed to read the text with due subtlety and understanding. But once the problem-solving function of exegesis was recognized, it also became "more and more the primary field of doctrinal conflict' (Williams 2001: 148). Although few Reformed theologians would identify with Origen's spiritual readings of the texts of Scripture, they would agree that prayerful, virtuous reading was necessary to properly understand the text of Scripture and that the meaning of particular passages was the hinge upon which controversy about paedobaptism turned.

The texts at issue in the controversy between the Baptists and the paedobaptists were the same that informed the controversy that emerged in the 1640s: Genesis 17, 1 Corinthians 7, and Matthew 28. Both Baptists and paedobaptists agreed that in order for infant baptism to be licit, there had to be warrant jure divino from Scripture, but they disagreed about what that might mean. Baptists like Danvers and Grantham demanded an express dominical command for baptism. Danvers argued that if Infants Baptism had been any Appointment or Ordinance of Jesus Christ, there would have been some Precept, Command, or Example in the Scripture to warrant the same, but in as much as the Scripture is wholly silent therein, there being not one Syllable to be found in all the New Testament about any such practice, it may well be concluded to be no Ordinance of Jesus Christ' (Danvers 1673: 97-8; see also Grantham 
1671: 40). Paedobaptists urged, with greater subtlety, that one could make a deduction by 'good and necessary consequence' from the Scriptures to the practice by appealing to the continuity between Old and New Testaments (see Muller 1994; Firmin 1684: 13). Obediah Wills argued, for example, that

[a] thing may be commanded in Scripture implicitly, and by good consequence; and what is thus commanded, is as valid and obliging, as if it were in so many letters and syllables; and thus we affirm Infant-Baptism commanded. There are in Scripture clear Grounds and Principles from whence by just and warrantable Consequences it may be deducted, that the Children of Believers have right to Baptism (Wills 1674: 137).

The exposition of these texts and the sense on the part of paedobaptists that baptism of the children of believing parents could be sustained as an implicit command required belief in the continuity of the covenant of grace, the meaning of the seal of baptism and the benefits conferred by it, and the typological relationship between circumcision and baptism, all of which were contested by the Baptists.

Some paedobaptists on one level tried to meet Baptists on their own ground, to give them an express command for the baptism of infants, by adducing Matthew 28:19: 'Go ye therefore, and disciple all nations, baptizing them in the name of the Father, and of the Son, and of the Holy Ghost.' Richard Baxter argued from the 'exposition of the universal church' that this text included infants as disciples to be baptized (Baxter 1675: 209). That infants were not in a position to learn was immaterial because 'Ideots having not the use of reason from birth, are in the same case with Infants', and that

[a]s a mans hand or foot doth not understand by teaching, and yet is part of a Disciple that's made such by teaching; so Infants understand not, and yet are Infant Disciples, as being naturally so much appertaining to their Parents, that by Gods Law the Parents Will goeth for theirs in consenting for their good. They are Subjects before they obey... and so they are Disciples before they learn; and made such by that teaching which made their Parents such, and taught them to dedicate them to God (Baxter 1676: 18-19).

It was by being 'Branches of such a root as is called out of the World, they are called with him the Root and Branches going together, and they Members of the same church with their Parents under Ordinances' that infants acquired the right to baptism as disciples (Firmin 1688: 30). Other paedobaptists like Joseph Whiston disagreed with this approach, arguing that the weakness of this express command actually strengthened the Baptists's position. Paedobaptists like Whiston believed that the only availing argument was the indirect one from good and necessary consequence (Whiston 1675: 29). 
Baptists, presupposing that discipleship required actual teaching and thus the ability to understand in the subject, easily rejected this explicit command. 'Personal and actual faith they have none, for they have no acts of understanding', declared Thomas Grantham, and disciples are to be made by 'actual teaching' (Grantham 1671: 41): 'If those that are to be baptized according to actual teaching or learning from another, then no infant ought to be baptized according to this Text, but the first is true: Ergo, so is the latter' (Grantham 1674: 10-11). Likewise Danvers urged that 'Infants of 8 or 10 dayes old can neither judge nor speak' and thus they should be treated like catechumens, not disciples capable of baptism (Danvers 1673: 48, 108).

Applying the argument from good and necessary consequence, Joseph Whiston countered the Baptist insistence upon reasonable assent by distinguishing between different ends of baptism, and he argued that infants were capable of receiving two of these: "to seal confirm and ratify the Covenant with the Promises thereof' and 'to give those a solemn admission into the visible Church, who have an antecedent right thereunto'. To argue against baptizing infants on the grounds that they are incapable of some ends of baptism, even though they are capable of the 'main and Principal Ends and uses of Baptism... is a wild way of arguing' (Whiston 1675: 40-1). Baptists remained unconvinced because they rejected Whiston's (and other paedobaptists's) account of the ends of baptism.

Paedobaptists also tried to show that the Baptist rejection of an independent command for baptism was self-defeating. Henry Danvers objected that there is no express Command or Example for Womens receiving the Lord's Supper' by adducing Acts 1:14, where 'we read that Mary and the other Women were gathered together... and continued steadfastly in the Apostles Doctrine and Fellowship, and breaking of Bread and Prayers, Chap. 2.42. 44. It being expressly said, That all that believed were together'. He added that 1 Corinthians 11 also provided a warrant for women taking the Lords Supper. If as good a warrant for infant baptism could be adduced, he would accept it (Danvers 1673: 105-6). Richard Blinman, writing under the pseudonym 'Ereunalathes', set out to prove that 'this Example that you bring (and the command also...) is not so express, nor so clear, as you make it to be', 'that there is as much room for Objections against it as there is for Objections against the Baptizing of Infants', and 'all the evidence that your Example and Command will afford you, for Womens receiving the Lords Supper, you must deduce, by way of consequence, and that very darkly too, from what you bring' (Blinman 1674: 2, 75). The women were not expressly referred to as believers in Acts 1:14, the assembly mentioned in 2:42-4, in which the breaking of bread is mentioned, is not the same assembly as 1:14 and does not expressly mention the women, and moreover, the gender of the Greek phrase in 2:44, pantes de hoi pisteuontes, limits the referent of those who were 
breaking bread to the men (Blinman 1674: 3-4). Likewise with other texts Danvers adduces to prove the institution explicitly. The term anthropos in 1 Corinthians 11 can have a general signification, but when paired with masculine nouns it referred to men (Blinman 1674: 8-9). Thus to infer that women were part of the assembly breaking bread together, one had to do so implicitly, by good and necessary consequence. By analogy, one must also allow arguments for the inference by good and necessary consequence for baptism (Blinman 1674: 76).

Baptists, unsurprisingly, did not find Blinman's point compelling, but in a sense the treatise also missed the point, which was that Baptists rejected the continuity in the covenant of grace asserted by paedobaptists between the Abrahamic and Christic administrations. When pressed to defend the practice of infant baptism, paedobaptists univocally pointed to the institution of circumcision in Genesis 17 as the confirmation that the children of believing parents belonged in the covenant with their parents and so should receive the seal of the covenant. Joseph Whiston asserted that 'the New Testament Dispensation, differs not at all from the Old; in regard of the matter or subjects the Church is constituted or made up of; they were then the spiritual seed of Abraham, including their Infants, and so they are still' (Whiston 1675: $45)$. The argument here depended upon the continuity of the covenant of grace between the two Testaments: circumcision sealed the covenant in the Abrahamic and Israelite administrations of the covenant of grace in the same way that baptism sealed the covenant of grace in its Christic administration. As Giles Firmin put it, circumcision and baptism were both 'initiating' ordinances in different dispensations for the covenant of grace (Firmin 1688: 28).

The paedobaptists sought further confirmation from 1 Corinthians $7: 14$, which suggested that the children of believers were 'holy' (hagia) and which the paedobaptists interpreted as meaning that they belonged in the covenant with their parents. Obediah Wills claimed that this term did not mean regeneration in this context, but instead 'the Children of either believing Parent, are holy with a holiness-relation put upon them, and separation to God, as his peculiar people, by virtue of which, they have a right to the external privileges of the Covenant, whereof they are as capable as the children of the faithful Israelites' (Wills 1674: 160). The continuity between the two testaments was such that one would expect to find an express command from Christ not to baptize infants rather than a positive command for its institution: 'the New Testament doth give us clear Texts to prove the Church-membership of believing Parents; you cannot give us clearer Texts for their unchurching, unless you give us express Scriptures' (Firmin 1684: 57).

Henry Danvers, like Thomas Grantham, Knollys Hanserd, and other Baptists insisted that the Old Testament type did not find its fulfillment in 
Baptism in the New Testament. They did not agree exactly on how to conceive of the relationship between the Abrahamic covenant and the covenant of grace under Christ, but they agreed upon a disjunction between them. For Danvers, the Abrahamic covenant was a 'mixt' Covenant, partially regarding Abraham as father of the 'Natural Israelites' and partially regarding him as father of 'Spiritual Israel'. Circumcision was a seal of Abraham's faith which preceded circumcision, but it was not administered to infants as a seal of their faith, first because it was nowhere called a seal in the New Testament (it is called a 'figure' in 1 Peter 3:21) and secondly because it 'belonged to all the natural Linage, and posterity of Abraham good and bad, without any such limitation, as was put on Baptisme' (Danvers 1673: 206-7, 219; see also De Laune 1677: 15-16). The disjunction was sharp, because baptism followed repentance and was 'to evidence present regeneration, whereof it is a lively sign or symbol' (Danvers 1673: 18) whereas circumcision was administered to all without regard to regeneration. Moreover, there was a disjunction in the kind of sign baptism was in comparison with circumcision. Circumcision was a 'sign not improper for Infants; because it left a signal impression in their flesh to be remembred all their days, but so cannot Baptisme be to any Infants' (Danvers 1673: 218). Paedobaptists did not see this as a weighty objection, because just as baptized infants had to rely upon the testimony of others to do determine the meaning of that baptism, so also did circumcised infants rely on the testimony of others to know what the meaning of their circumcision was (Firmin 1684: 48).

There was in reality no sense of baptism 'sealing' anything for the Baptists, since for them the only seal in the New Testament was the Holy Spirit (Danvers 1673: 218, 221). Baptism was a figure or sign representing to one already regenerate the mystery of salvation that had taken place inside of him or her (De Laune 1677: 17-18). As such, there was no positive benefit to be had from an infant receiving it; it did not regenerate nor confer any grace in and of itself. The Dissenting paedobaptists, as anti-sacramentalists themselves, were uncertain about how to articulate what efficacy baptism had for the infant (see Holifield 1974: 76). They allowed that grace might be communicated through it in the case of elect infants, but this certainly did not happen in every case. Some of them talked about it as the entrance or initiatory rite into the church, but this formulation did not receive universal acceptance either. They all insisted, however, that a seal was something other than a mere sign (see, for instance, Firmin 1684: 69). On this point, Baptists and paedobaptists were deeply divided.

Although paedobaptists were ostensibly making doctrinal inferences from objective canonical exegesis, as Paul Lim has indicated analogously in the context of antitrinitarian disputes in the 1670s and 1680s, the paedobaptist disputants were now 'keenly aware that no biblical exegesis could stand on its 
own unless one could demonstrate that one's exegesis put him in the middle of the historical stream of "faithful exegetes" (Lim 2012: 221). The Baptists were suspect to the paedobaptists because they were offering a novel reading of the text of Scripture, as Giles Firmin indicated in The Plea of the Children: 'To me it seems strange, and so strange, that I will never believe it, That Christ should Promise his Spirit to the Church, and that good Spirit should suffer both his Martyrs and choice People to err in such a Point (if it be an Error) from the Apostles days to this day' (Firmin 1683: 3, 12). This was in a sense tantamount to arguing that infant baptism was probably right because it was the longstanding tradition of the church. The paedobaptists now found themselves in the uncomfortable posture of defending the tradition of baptizing infants against Baptists who claimed that the plain letter of the text could not sustain it.

Obediah Wills insisted that the Baptist reading was idiosyncratic and novel, and therefore represented a new kind of hermeneutical tyranny akin to Popery: 'But you must understand he means by himself and his party that have made such inquisition and search into Scripture, that they only have found what is there; what they judge to be the sence of Scripture is so, and we must all come and learn of them what may be inferred from it, what not. Away with this Popery' (Wills 1674: 158). By contrast, the paedobaptists contended, they were reading the text of Scripture according to the analogia fidei or analogy of faith, which avoided the extremes of Baptists and the Papists:

I shall readily confess, that Infant-Baptism of Inchurch-Parents, keep us upon the old bottom of that Ancient Covenant of Grace, made with Abraham, and his Church-Seed, as well as his spiritual Seed; and that is no dishonour nor damage to us. But it keeps us not upon the old Romish Antichristian bottom; nor doth it make us symbolize with the Church of Rome, as it is now Antichristian; but the Church of Rome, as it was once Apostolique, planted and watered by the Apostles (Blinman 1674: 215).

The paedobaptists were putatively charitable in this moderate self-fashioning: they were willing to keep communion with Anabaptists so long as the latter would not separate, despite differences of opinion on exegesis. Giles Firmin, for instance, alleged that the Baptist pugilists were schismatic: 'you are the Schismatick, for I have kept Communion with a godly Anabaptist; but one tells me, that he desired Communion with one of your Churches, but they would not admit him to Communion, because he would not be Dipped' (Firmin 1684: 23). Henry Danvers insisted, in his response to Obediah Wills, by contrast, that the only way to justify the paedobaptist position was by popish appeal to tradition: 
though Mr. Wills affirms that there is such a vast difference betwixt the Church of Rome, and them, in the point of Tradition about Infants Baptisme, wherein he owns them too corrupt; yet for my part I see not, as Mr. Wills represents, the Protestant sentiments about it, where the vast difference lyes, and what reason he had to conclude, they themselves, that hold with the Fathers herein, are so Orthodox, and the Papists so corrupt, and Heterodox (Danvers 1675c: 73; see also Danvers 1675a: 44, 46-7).

Thomas De Laune argued that 'the way of arriving to Scripture-knowledge, is not through the gaudy portals of Philosophy, and artificial ratiocinations, but by an earnest waiting, and address to the Lord in Prayer and Scripture meditation' (De Laune 1677: sig. A4v). The exegetical and hermeneutical questions at the heart of the controversy elicited rival, mutually incommensurable answers from the Baptists and the paedobaptists, and the defensiveness of the paedobaptists indicated the degree to which the polemical ground on paedobaptism had shifted post-Restoration.

\section{The Matter and Form of Baptism}

The question of who was a fit subject for baptism could, in a sense, be answered identically by paedobaptists and Baptists. Both agreed that the 'matter' of the church was 'visible saints', which meant that adults evidencing repentance according to the 'Rational-Charity' of the church were the fit subjects of baptism. That paedobaptists admitted as much led to the embarrassing reality that Baptists could ransack paedobaptist writings for support for their own cause. This was an effective rhetorical practice, even though Obediah Wills could protest that 'you know Baxter, Piscator, Perkins, Pareus, Calvin, all speak of grown Persons' and that 'as for the Infant Seed of Believers the case alters there; for they being taken into the Covenant with their Parent, it is instead of Profession' (Wills 1674: 283; see also Whiston 1676: 15; Collinges 1681: 27; Petto 1674: 263). As Wills suggests, however, paedobaptists dissented from the Baptists by arguing that children were accepted in the covenant not in virtue of themselves, but insofar as they were the seed of believing Christians. The agreement upon the question of the matter of baptism, however, seemed dispositive to the Baptists. Danvers wrote that the danger of an impious person baptizing his or her children was so great that the admission that visible saints were the only fit subjects of baptism pulled up the practice 'root and branch' (Danvers 1675b: sig. A1r).

While being careful to distinguish their position from baptismal regeneration, paedobaptists wanted to urge that the inclusion of children within the covenant conveyed special privileges to them, such that the seal of the covenant should be maintained. Thomas Hooker had earlier distinguished, for instance, between the 'internal' and the 'external' covenant on the basis of 1 Corinthians 7:14, which described the federal 'holiness' of the children of 
believing parents (Hooker 1649: 78-9). Wills similarly distinguished between 'common' and 'saving' grace, the former of which consisted of the privileges of access to the gospel and membership in the visible church, but from which it was possible to fall away. Baptism might also convey special grace in some cases, but this could not be guaranteed, as many seeming Christians did in fact exhibit only temporary faith. However, this falling away was not an argument in favor of adult baptism, because adult converts were just as likely to fall away as children raised in the church (Wills 1674: 188).

Although he did not share it, Wills was also willing to distinguish the baptismal regeneration proclaimed in the Book of Common Prayer from the Catholic teaching on baptismal regeneration for the sake of polemics (Wills 1674: 268). As a general matter, the paedobaptists found themselves in disagreement with each other as much as with the Baptists on the question of whether baptism signified entry into the visible church or not. Whereas Hooker, Wills, and others seemed to think this a reasonable expression of what was happening, siding in this sense with the Anglican polemicists against the Baptists, Baxter and Blinman thought that this way of expressing the sense of the rite obfuscated more than illuminated and gave the Baptists an argumentative foothold more than was necessary. For them, children already belonged in the covenant prior to the baptism, and baptism sealed and solemnized what was already the case. According to Blinman, for instance,

The End of Baptism I conceive is not, that the Baptized Person, may orderly thereby, have an entrance into the visible Church. Nor was Circumcision of old, the visible door of Entrance into the Old-Testament-Church. For, Baptism presupposeth the person to be a Member of the visible Church, and so did Circumcision. And though some of those that are for Infant-Baptism, use such expressions; yet I suppose by their discourse in other places, they mean, that it was only a solemn establishment and sealing of that Covenant in which they were before (Blinman 1674: 37; see also Baxter 1656: 73; Baxter 1675: 124-5; Lim 2004: 64-5).

Although the matter of the church was for Blinman and Baxter, as with the Baptists, 'visible saints', they wanted to include children as, in Blinman's expression, 'Mediate-Members' (Blinman 1674: 54). Baxter preferred to say that 'the Covenant or Law of Grace giveth visible Church-membership conditionally to all that hear it', or that provided that the covenant is eventually owned, the seal is effectual (Baxter 1675: 99). Moreover, the argument that seemed to avail with Danvers and other Baptists, that 1 Corinthians 7 did not provide a sufficient exegetical basis to baptize the infants of believers because some whose children were baptized would prove hypocrites could easily be turned back upon the Baptists: 'It seems then, that you Baptize no Hypocrites; and I heartily wish you did not. Do you certainly and infallibly know, 
that all that are Baptized in your way, are true real Christians, and not Hypocrites? Surely that cannot be known by you' (Blinman 1674: 100; see also Baxter 1676: 25; Firmin 1684: 10).

The form of baptism occasioned much greater disagreement. Baptists argued that the only administration of baptism that had warrant from Scripture was a trine immersion of a believing person manifesting repentance, whereas paedobaptists defended the traditional practice of ablution or washing, which the Baptists insisted upon calling 'sprinkling' (Blinman 1674: 186-200; Wills 1674: 242-3). The disagreement largely revolved around the question of what was signified by baptism, and both sides were able to draw upon scriptural imagery to defend their understanding. Both parties were clear that the sign must image the thing signified. For the Baptists, it was clear from Romans 6:1ff and Col. 2:11ff that there was a visible 'agreement between Baptism and the death, burial, resurrection of Christ, our death to sin, burial, and rising with him to a new life' (Grantham 1678: ii.ii.28). The only symbolic action that could image such a signification was immersion under the water for death, and rising again out of the water for resurrection.

Henry Danvers also indicated that 'the eminent thing signified and represented in Baptsme, is not simply the blood of Christ, as it washeth us from our sin; but there is another representation therein of Christ's Death, Burial and Resurrection in the Baptized, being first buried under Water, and then rising out of it, and this is not in a bare conformity to Christ, but in a representation of a Communion with Christ in his Death and Resurrection' (Danvers 1673: 251). The paedobaptists, by contrast, insisted that 'if Circumcision signified Heart Circumcision, to those that were Circumcised, then it must also signifie Remission of $\sin$ and Justification by the Blood of Christ; and Sanctification also', and thus baptism as the antitype to circumcision also signified cleansing from sin. As such, washing was the appropriate modality of administering baptism, because 'unless you rinse or rub, as well as dip, you will not easily make clean work of it; and if this your similitude hold, you must not only dip the person you Baptize, but you must rinse or rub him too, to signifie his cleansing' (Blinman 1674: 169, 199; see also Firmin 1684: 113).

Baptism by 'dipping' also possessed a potentially salacious consequence as well. Unless one baptized the person naked, one would only be baptizing the person's clothes rather than the person him or herself. But Christ, who was 'a pattern of holiness' surely would not have been baptized naked; likewise it would have been 'unsuitable to Christian-modesty' for Philip to baptize the Ethiopian Eunuch naked (Blinman 1674: 192, 195; see also Baxter 1676: 37). The paedobaptists, while contending for the traditionalist practice of ablution, also asserted for the most part that the mode was indifferent (Petto 1687: 77). This was, of course, to a great extent moderate self-fashioning, as the 
paedobaptists had no intention of expanding or altering their practice to include immersion, but they allowed that both practices were lawful to demonstrate their magnanimity and eagerness to commune with all 'sober' or 'godly' Anabaptists.

\section{Conclusion}

Debates over baptism in the post-Restoration era in many ways perpetuated rancorous disputes that began during the English Civil War. As Paul Lim has written about disputes over Calvinism in the Restoration, 'rather than the Restoration being a major rupture, thus making it little connected to the battles of the 1640s and 1650s, it is clear that strikingly similar battles were raging in the mid-1670s as well' (Lim 2012: 214). The Restoration debates draw to the fore the polemical, exegetical, and theological questions at the heart of these debates, however: the causes of societal stability and instability, the proper manner of reading Scripture canonically, and the meaning of the socalled 'regulative principle' of reading Scripture.

\section{Bibliography}

\section{Primary Printed Sources}

Anonymous (1674) Baptism, Infant-Baptism, and Quakerism. London.

Anonymous (1678) Some Brief Directions for Improvement of Infant Baptism. London.

Baxter R (1656) Plain-Scripture Proof of Infants Baptism. London.

Baxter R (1675) More Proofs of Infants Church Membership. London.

Baxter R (1676) Rich. Baxter's Review of the State of Christian's Infants. London. Bedford T (1638) Treatise of the Sacraments. London.

Blinman R (1674) An Essay Tending to Issue the Controversie about Infant Baptism. London.

Collinges J (1681) The Improvableness of Water Baptism. London.

Danvers H (1673) Treatise of Baptism. London.

Danvers H (1675a) A Second Reply. London.

Danvers H (1675b) Treatise of Baptism, 3rd edition. London.

Danvers H (1675c) Truth and Innocency Vindicated. London.

Danvers H (1676) A Third Reply, or a Short Return to Mr. Baxters Brief Answer to My Second Reply. London.

De Laune T (1677) Truth Defended. London.

Firmin G (1684) The Plea of the Children of Believing Parents. London.

Firmin G (1688) Scripture-Warrant Sufficient Proof of Infant Baptism. London.

Fox G (1676) Concerning the True Baptism and the False. London.

Grantham T (1663) The Baptist against the Papist. London. 
Grantham T (1671) The Paedobaptists Apology for the Baptized Churches. London. Grantham T (1674) A Religious Contest. London.

Grantham T (1676) The Quaeries Examined. London.

Grantham T (1678) Christianismus Primitivus. London.

Grantham T (1680) The Controversie about Infants Church-Membership and Baptism. London.

Hooker T (1649) The Covenant of Grace Opened. London.

Petto S (1674) The Difference between the Old and New Covenant Stated and Explained. London.

Petto S (1687) Infant Baptism of Christ's Appointment. London.

Whiston J (1675) The Right Method for the Proving Infant-Baptism. London.

Whiston J (1676) Infant Baptism from Heaven and not of Men, the Second Part. London.

Wills O (1674) Infant Baptism Asserted and Vindicated by Scripture and Antiquity. London.

Wills O (1675) Vindiciae Vindiciarum. London.

Secondary Sources

Holifield E (1974) The Covenant Sealed: The Development of Puritan Sacramental Theology in Old and New England, 1570-1720. New Haven, CT: Yale University Press.

Lim P (2004) In Pursuit of Purity, Unity, and Liberty: Richard Baxter's Puritan Ecclesiology in Its Seventeenth Century Context. Leiden: EJ Brill.

Lim P (2012) Mystery Unveiled: the Crisis of the Trinity in Early Modern England. New York, NY: Oxford University Press.

Muller R (1994) The Covenant of Works and the Stability of Divine Law in Seventeenth Century Reformed Orthodox: A Study in the Theology of Herman Witsius and Wilhelmus à Brakel. Calvin Theological Journal 29(1): 75-101.

Williams R (2001) Arius: Heresy and Tradition, revised edition. Grand Rapids, MI: Eerdmans. 